\title{
Irish-Potato Farming in Plateau State, Nigeria: A Profitability Analysis
}

\section{Ogheneruemu Obi-Egbedi \& Dominic Midawa Gulak}

Department of Agricultural Economics, University of Ibadan, Nigeria. Email: gheneobi@gmail.com, dominicmidawa@gmail.com

\section{Received: 06.01.2020 Accepted: 14.05.2020 Date of Publication: June, 2020}

\begin{abstract}
Notable efforts are on-going to improve Irish potato production in Plateau State, the major producer of the crop in Nigeria. However, little attention has been given to the profitability of the enterprise while the determinants of profitability level are scanty in the literature. Thus, paper analyses the profitability of Irish-potato farming using primary data from 252 Irish potato farmers in Plateau State, Nigeria. Cost structure and profitability level of Irish potato farming were investigated using farm budgeting technique while probit regression model was used to examine the determinants of profitability level of Irish potato farms. Irish potato farming was found to be profitable with most $(53.97 \%)$ farmers at high profitability level. The net farm income was $\$ 604,245.81$ per hectare with returns per naira spent of 1.70. The cost structure showed that costs of seeds, labour and fertilizer made up the largest share of the total cost of production per hectare. The probability that a farm will be at high profitability level was determined by agrochemicals, sex, farm size and labour at $1 \%$ level, respectively. It was concluded that increasing agrochemicals, reducing farm size and labour and being a male farmer will improve profitability level of Irish potato farms. This study recommended that increased use of agrochemicals and more efficient use of labour and farm land be encouraged among potato farmers increase their profitability level.
\end{abstract}

Keywords: Profitability level, Cost structure, Farm budgeting, Irish potato, Net farm income.

\subsection{Introduction}

Irish potato (Solanum tuberosum L.) is the world's fourth largest food crop in terms of production after maize, rice and wheat (FAOSTAT, 2016). It is thus, the largest non-cereal food crop 
cultivated in the world. It was first cultivated in South America (Zhang et al., 2016) and easily substitutes for cereals in many developing countries; making Irish potato very crucial for food security. Global output of Irish potato is about 388 million metric tonnes with a yield per hectare of $20,110.8 \mathrm{~kg} / \mathrm{ha}$. Over half of the global output is produced in developing countries, almost one-third of the output is harvested in China and India alone while China is the leading producer in the world with 99 million metric tonnes (FAOSTAT, 2019).

Irish potato production in Africa is estimated at 25 million metric tonnes with yield per hectare of $13,215.4 \mathrm{~kg} / \mathrm{ha}$, and per capita consumption (fresh and processed) of $18.76 \mathrm{~kg} / \mathrm{capita} /$ year (FAOSTAT, 2019). Algeria is the leading producer of Irish potato in Africa with a production 4,606,400 metric tonnes, followed by Egypt $(4,325,480$ metric tonnes) and South Africa $(2,450,540$ metric tonnes). Nigeria's production of $1,284,370$ metric tonnes ranks seventh in Africa after Morocco $(1,924,870$ metric tonnes), Tanzania $(1,749,201$ metric tonnes) and Kenya, the fourth to sixth largest African producers (FAOSTAT, 2019).

Irish potato is a major root crop in Nigeria and is by far the most efficient tuber crop in terms of tuber yield and days to maturity. It matures in about 8090 days as compared to 9-12 months for yam and cassava (Sanusi and Babatunde, 2017). Nigeria's production level has been on the increase with yield per hectare of 3,720.1 $\mathrm{kg} / \mathrm{ha}$ (FAOSTAT, 2019). Domestic consumption of both fresh and processed Irish potato stands at 4.63 $\mathrm{kg}$ /capita (FAOSTAT, 2015). Irish potato was introduced to Nigeria in the early 19th Century when it was first planted in the Jos Plateau (Taiy et al., 2017; Tadesse et al., 2018). Plateau State has an average maximum temperature of $31.7 \mathrm{oC}$ and a minimum temperature of $15 \mathrm{oC}$. The highest temperatures are recorded in the months of March to May while the lowest temperatures are between December and January (Harmattan months). Thus, a rainfall season running from April to October and a dry season with a cold dry harmattan wind that prevails over the state from November to February. This gives the state a near temperate climatic condition that favours the cultivation of crops like Irish potato which require an optimum temperature of $150 \mathrm{C}$ for tuber formation (Okonkwo et al., 2009). The Jos-Plateau meets this condition in both rainy and dry season, thus making the crop one of the most important root crops grown on the JosPlateau. It is currently widely cultivated in commercial quantities in Plateau state. The State is notably the most important area for potato production in Nigeria as over $80 \%$ of Irish potato produced in the country come from Plateau State (Muhammed et al., 2016). Other Irish potato producing states in Nigeria include Kaduna and Taraba States. The crop has become a marketable crop used for different purposes. It is consumed majorly fresh as a vegetable, processed into other potato food products (snacks, fries, crisp) and used as food ingredients. Non-food uses include: starch for

URL: http://journals.covenantuniversity.edu.ng/index.php/cjbss 
industry, animal feed, glue and re-used as seed tubers (Ojo, 2013).

Due to the increasing number of uses to which Irish potato can be put, production activities have been increasing. Profitability is the main objective of production and is important to every farmer, as it will not only improve farmers' income and livelihood but would also influence the farmers' adoption of new technologies (AshleyDejo et al, 2016). A study carried out by Jwanya et al. (2014) examined the economics of Irish potato production in Plateau State. The result showed that Irish potato production in Plateau State was a profitable lucrative enterprise with robust economic viability as indicated by the values of Gross Margin (N655.88), benefits -cost ratio (2.64) and sensitivity analysis ration (2.16). The finding of the profitability analysis of Jwanya et al. (2014) is in consonance with other studies on Irish potato, some of these included the works of Nyagaka, Obare and Nguyo (2009), Obare, Nyagaka and Nguyo (2010), and Njuguna, Munyua and Makal (2014). The prevailing constraints to potato production and value chain in Nigeria would also affect the profitability level of the enterprise. Ugonna et al. (2013) and Tolno et al. (2016), identified some of the constraints to include: pests and diseases, climate related factors, lack of credit, inadequate supply of quality seed, poor storage, high cost of production inputs and marketing problem, poor irrigation and, labour shortage. Thus, measuring profitability levels is necessary in order to determine if the enterprise is worth committing scare resources. Moreover, the salient factors that determine profitability level are important in order for farmers to know where they should focus their attention on to be highly profitable.

Empirical studies on the profitability of potato and other tuber crops in other States of Nigeria, apart from Plateau State, exist (Muhammad et al, 2016; Adekanye and Oyekale, 2015; Ogunleye and Adeyemo, 2017) while only Jwanya et al. (2014) was found to assess profitability of Irish potato in Plateau State, with the finding that it is a profitable enterprise. Most studies assessed the determinants of production and efficiency rather than the profitability of potato (Jatbong et al, 2018; Gebru et al, 2017; Tolno et al, 2016; Adekanye and Oyekale, 2015). Determinants of Irish potato profitability were therefore inferred from these empirical studies to include: education, sex, age, farm experience, farm size, agrochemicals, household size, marital status, type of land ownership and cooperative membership. The sex of the farmer is expected to affect profitability level due to the tedious nature of Irish potato farming and female farmers' cultural restrictions to production inputs access (Gebru et al, 2017). Age and farm experience are expected to increase the probability of being highly profitable due to knowledge of farm operations and ability to manage risks. Similarly, years of formal education and cooperative membership are expected to increase the probability of being highly profitable due to ability to understand and adopt innovation and exposure to knowledge of improved farm practices (Jatbong et al, 2018; Gebru et al, 2017; Sher et al,

URL: http://journals.covenantuniversity.edu.ng/index.php/cjbss 
2016 and Tolno et al, 2016). Larger household size and farm size may increase the probability of being highly profitable due to more family labour availability and economies of scale, respectively but this is not conclusive in the literature (Sebatta et al. 2015; Okoye et al, 2008).

Notable efforts are on-going to improve Irish potato production by the Potato Research Centre, Kuru-Vom in Plateau State through seeds multiplication, training of farmers, Irish potato research, breeding and selection of new varieties that are capable of responding to improved cultural practices (Zemba et al., 2013). In the same vein, several studies have been carried out on Irish potato in Plateau State which focused on the productivity, resources use, marketing, nutrition, output, climatic conditions and price dynamics (Lenka et al., 2006; Nweze et al., 2006; Kudi et al., 2008; Dimlong, 2012; Wuyep et al., 2013; Zemba et al., 2013; Panwal 2018). Little attention has been given to the profitability of the enterprise as in the studies of Okonkwo et al. (2009); Jwanya et al. (2014). Hence, the following research questions are raised: Is Irish potato farming profitable? What is the profitability level of Irish potato farmers? What is the cost structure of Irish potato farms? What are the factors affecting profitability level of Irish potato farmers? This research therefore aims to assess the profitability level, cost structure and determinants of profitability level of Irish potato farms in Plateau State, Nigeria.

\subsection{Material and Methods}

This study was carried out in Plateau State, located in North Central Nigeria.
Plateau State produces about threequarters of the country's Irish potatoes according to PADP (2002) and FAOSTAT (2020). The State lies between latitude $80 \mathrm{~N}$ and $100 \mathrm{~N}$ and longitude $70 \mathrm{E}$ and $110 \mathrm{E}$ of the prime meridian. Average maximum temperature is about $31.7 \mathrm{oC}$ (usually between March-May) and minimum temperature about $15 \mathrm{oC}$ (usually between December-January) while the rainfall season runs from April to October. Thus, the weather mimics a temperate climatic condition which favours Irish potato production. Other crops produced in the State include: cabbage, onions, carrots, lettuce, cucumber and green beans.

Primary data was collected based on the 2018 farming season using a wellstructured and validated questionnaire. A multi-stage sampling method was used for the survey. In the first stage, two (2) local government areas were randomly selected out of the five major Irish potato producing local government areas of Plateau State. These were Bokkos and Mangu. The next stage involved a simple random sampling of three (3) districts each from the list of eight (8) districts in each of the two (2) local government areas. This gave a total of six (6) districts from which three (3) villages each were selected randomly from the list of villages, giving a total of eighteen (18) villages. The last stage involved a random sampling of Irish potato farmers from the 18 villages in proportion to their size. Thus, a total of 260 Irish potato farmers were selected but only 252 gave complete information and were used for data analysis.

URL: http://journals.covenantuniversity.edu.ng/index.php/cjbss 
Data were analysed using descriptive statistics, farm budgetary technique and probit regression model. Descriptive statistics was used to profile the socioeconomic characteristics of the Irish potato farmers and their level of profitability (high or low) while the farm budgetary technique, also called net farm income analysis, was used to examine the profitability level and cost structure of Irish potato production. The probit regression model was used to analyse the determinants of the profitability level of the Irish potato farms, that is, the probability of having high level of profitability in Irish potato farming in the study area.

\section{A. Farm Budgeting}

The net farm income derived from Irish potato production is explicitly stated following Bathon et al. (2016);

$\mathrm{NFI}=\mathrm{GR}-(\mathrm{TFC}+\mathrm{TVC})$

Where;

NFI is the Net farm income ( $)$, GR is the Gross revenue ( $)$, TFC is the Total fixed costs ( $)$ and TVC is the Total variable costs $(N)$.

$\mathrm{TC}=\mathrm{TFC}+\mathrm{TVC}$

$\mathrm{TR}=\mathrm{P} . \mathrm{Q}$

Where;

$\mathrm{P}=$ Price of Irish potato produced in

Naira per kilogram, $Q=$ Output of Irish potato produced in kilogram.

Further, the Benefit-cost Ratio (BCR) was also estimated following Udensi et al., 2017; Sujan et al., 2017.

Benefit-cost Ratio $=\frac{\text { Total Revenue }}{\text { Total Cost }}$

The Rate of Returns on investment (ROI) was also estimated following Ogunleye and Adeyemo (2017).
Return on investment $=$

Net farm income

Total Cost

The Net Farm income ratio $=$

Net farm income

Total revenue

\section{B. Probit Regression Model}

The probit regression model was used to analyze the determinants of the level of profitability of Irish potato farming. The farmers were categorized as being at low or high profitability level. The mean profitability was used, thus, all farmers that had less than the mean profitability were categorized as being at low profitability while those who had up to the mean and above were at high profitability. Hence, the dependent variable; profitability; was dichotomous. The method of maximum likelihood estimation of the probit model automatically accounts for the heteroskedasticity problem (Masuku et al., 2015). The probit model is implicitly expressed as:

$\operatorname{Pr}(y=1 \mid x)=\phi\left(\beta_{i} x_{i}\right)$

Where;

$\phi$ is the standard cumulative normal distribution with mean 0 and variance 1. $\beta_{i}$ are the estimated coefficients of the model. $\mathrm{Y}$ is a function of $\mathrm{X}_{1}, \mathrm{X}_{2}, \mathrm{X}_{3}$, $\mathrm{X}_{4}, \mathrm{X}_{5}, \mathrm{X}_{6}, \mathrm{X}_{7}, \mathrm{X}_{8}, \mathrm{X}_{9}, \mathrm{X}_{10}, \mathrm{X}_{11}, \mathrm{X}_{12}, \mathrm{e}_{\mathrm{i}}$ Therefore, equation (7) is transformed as:

$P(Y=1 \mid x)=\beta_{1}+\beta_{2} x_{1} \quad$ (Gujarati, 2004). Then the model is explicitly stated as:

$Y=\beta_{0}+\beta_{1} x_{1}$

$+\beta_{2} x_{2}+\beta_{3} x_{3}+\beta_{12} x_{12}+e_{i}$ 
Where;

$\mathrm{Y}=$ Profitability level $(1=$ high profitability level, $0=$ low profitability level),

$\mathrm{X}_{1}=$ Years of formal education (Years),

$\mathrm{X}_{2}=$ Access to credit $(1=$ credit access;

$0=$ otherwise),

$\mathrm{X}_{3}=$ Marital status (1=Married;

$0=$ Otherwise),

$\mathrm{X}_{4}=$ Farming experience (Years),

$\mathrm{X}_{5}=$ Farm size $(\mathrm{Ha})$,

$\mathrm{X}_{6}=$ Household size (Number of

persons in the household),
$\mathrm{X}_{7}=$ Quantity of Irish potato seed planted $(\mathrm{Kg})$,

$\mathrm{X}_{8}=$ Labour (mandays)

$\mathrm{X}_{9}=\operatorname{Sex}(1=$ Male; $0=$ Female $)$

$\mathrm{X}_{10}=$ Type of cooperative $(1=$ producer, $0=$ otherwise),

$\mathrm{X}_{11}=$ Land tenure system

( $1=$ Inheritance; $0=$ otherwise), $\mathrm{X}_{12}=$ Agrochemicals (litres)

$\beta_{1}-\beta_{12}=$ Parameters to be estimated $\mathrm{e}_{\mathrm{i}}=$ Error term.

Table 1: Description of variables and their a prior expectation

\begin{tabular}{lll}
\hline Variable & Measurement & $\begin{array}{l}\text { A prior } \\
\text { expectation }\end{array}$ \\
\hline $\begin{array}{l}\text { Educational level of } \\
\text { farmers }\end{array}$ & Years & + \\
Access to Credit & Dummy: $1=$ Yes; 0=No & + \\
Marital status & Dummy: $1=$ Married; 0=otherwise & \\
Farming Experience & Years & + \\
Farm size & Ha & $-/+$ \\
Household size & Number of persons & $+/-$ \\
Quantity of seed & Kg & - \\
Labour & Manday & - \\
Sex & Dummy: $1=$ male; $0=$ female & $-/+$ \\
Type of cooperative & Dummy: $1=$ producer; $0=$ otherwise & + \\
Land tenure system & Dummy: $1=$ owned; $0=$ otherwise & + \\
Agrochemicals & Litres & + \\
\hline
\end{tabular}

URL: http://journals.covenantuniversity.edu.ng/index.php/cjbss 


\subsection{Results and Discussions}

\section{Socioeconomic Characteristics by Irish Potato Farmers by Profitability Levels}

The socio-economics characteristics of the Irish Potato farmers in the study area across profitability levels are depicted in Table 2. The result showed that Irish potato farming is dominated by male farmers $(71.43 \%)$. This could be attributed to the tedious nature of Irish potato farming and female farmers' restricted access to production inputs; particularly land ownership due to cultural barriers. Male farmers also make up the larger part $(89.66 \%)$ of those at high profitability level. This is similar to what holds in many African countries as Gebru et al (2017) also reported $88.8 \%$ males among surveyed potato farmers in Ethiopia. Age is an important consideration in the production and profitability of farmers. Farmers within the age category of 4150 constituted the majority of Irish potato farmers with $38.89 \%$ and also the majority of those at high profitability level with $43.97 \%$. The mean age of the farmers was $48 \pm 11$ years, indicating that Irish-potato farming in the study area was dominated by an agile workforce that could handle any of the cultural operations in potato production. In addition, since the farmers are still in their active working age, it thus suggests that they will be able to combine many operations that can further reduce cost as opposed to if they were old and declined in physical ability. Jatbong et al. (2018) also found potato farmers in Plateau State to be about 47 years. Credit empowers farmers to carry out timely operations in agriculture. However, most (69.84\%) of the farmers had no access to credit, implying that most farm operations in the study area were funded by farmers' savings. This is contrary to Sher et al. (2016) who found credit access for most farmers. Furthermore, majority of the farmers $(73.81 \%)$ were married, of which $74.14 \%$ of farmers within this category were at high profitability level. This is a similar scenario in most African countries where family responsibilities are highly regarded. Households size is a critical consideration for family labour in farming activities for African countries, due to the possibility of substituting or complementing hired labour with family labour for farm activities. The mean household size is approximately $11 \pm 5$ persons, indicating a relatively large household size. This finding contradicts that of Gebru et al (2017) who found mean household size of less than 10 persons. Education is an important factor in farmer's adoption of farm innovation which improves their profitability. In terms of years of education, the farmers attained an average of $9 \pm 5$ years of education with only a small percentage of about $11.90 \%$ of the farmers having no formal education. Majority $(40.87 \%)$ of the farmers had at least 7-12 years of formal education out of which $42.24 \%$ were at high profitability level. Thus, suggesting that farmers in the study area are literate. The implication of this finding is that the prospect for the adoption of improved technologies and the ability to use resources more efficiently in Irish potato production is high. That is, the farmers have the capacity to adopt new

URL: http://journals.covenantuniversity.edu.ng/index.php/cjbss 
innovations and technologies if extended to them. New innovations on the other end come with advantages such as reduced harvesting period and make Irish potato to be available all year round and also receive high revenue. Jatbong et al (2018), Gebru et al (2017) and Sher et al. (2016) also found most potato farmers having primary education or higher. Farming experience enables farmers to apply more efficient measures in their farming operations which lead to higher profitability. The results showed that the farmers were quite experienced in potato farming as over $80 \%$ had experience of above 10 years while the average year of potato farming was 18 years. This implies that the farmers were able to employ efficient production methods and also better deal with production risks. Jatbong et al (2018) also found that potato farmers had about 18 years of experience on the average. Farm size is also an important factor in profitability since it is assumed that the larger the farm size the more the farmer can take advantage of economies of scale and thus, increase profitability. The results however, showed that the farmers had an average farm size of $2.3 \pm 1$ hectares, implying that most of the farmers were small-scale farmers as categorized by Olayide et al. (1980) in Haruna (2010) which put small scale farmers in Nigeria into the category 0.16 hectares. This may have negative implications for high level profitability in potato production. With respect to use of agrochemicals, farmers applied an average of $454.0 \pm 267.6$ litres with majority $(33.73 \%)$ within the category of 401-600 litres, of which $43.10 \%$ were at high profitability level. It is expected that the quantity of agrochemicals used will impact positively on productivity and hence, profitability. Tolno et al. (2016) also found that potato farmers in Guinea used about $401 \mathrm{~kg} / \mathrm{ha}$ of agrochemicals. Similarly, the cooperative membership of farmers is expected to have positive effects on profitability due to the easier access to credit, inputs and information regarding farming activities. In addition, group production and marketing of their farm produce can help them benefit from economies of scale which could impact positively on members' profitability level. Majority of the farmers belonged to producer cooperatives (40.08\%), hence, it could have positive implications for their profitability level. Also, the type of ownership of farmland is an important factor in production activities and consequently, profitability. It is expected that farmers who own their land either by purchase or inheritance can make long term investments on the land which could bring about profitability. The results showed that most farmers inherited the land used for Irish potato production $(59.92 \%)$. This could have positive implications for profitability of the farmers. 
Table 2: Socio-economic Characteristics of Irish Potato Farmers Profitability Level

\begin{tabular}{|c|c|c|c|c|}
\hline Variable & $\begin{array}{l}\text { Low } \\
\text { profitability } \\
\text { level }\end{array}$ & $\begin{array}{l}\text { High } \\
\text { profitability } \\
\text { level }\end{array}$ & Pooled & Mean \pm SD \\
\hline \multicolumn{5}{|l|}{ Sex } \\
\hline Female & $60(44.12)$ & $12(10.34)$ & $72(28.57)$ & \\
\hline Male & $76(55.88)$ & $104(89.66)$ & $180(71.43)$ & \\
\hline \multicolumn{5}{|l|}{ Age (years) } \\
\hline$\leq 20$ & $3(2.21)$ & $1(0.86)$ & $4(1.59)$ & \\
\hline $21-30$ & $4(2.94)$ & $5(4.31)$ & $9(3.57)$ & \\
\hline $31-40$ & $22(16.18)$ & $26(22.41)$ & $48(19.05)$ & \\
\hline $41-50$ & $47(34.56)$ & $51(43.97)$ & $98(38.89)$ & \\
\hline $51-60$ & 45 (33.09) & $25(21.55)$ & $70(27.78)$ & \\
\hline $61-70$ & $14(10.29)$ & $6(5.17)$ & $20(7.94)$ & \\
\hline$>70$ & $1(0.74)$ & $2(1.72)$ & $3(1.19)$ & $48 \pm 11.02$ \\
\hline Access & & & & \\
\hline \multicolumn{5}{|l|}{ Credit } \\
\hline No & $98(72.06)$ & $78(67.24)$ & $176(69.84)$ & \\
\hline Yes & $38(27.94)$ & $38(32.76)$ & $76(30.16)$ & \\
\hline \multicolumn{5}{|l|}{ Marital Status } \\
\hline Single & $18(13.24)$ & $24(20.69)$ & $42(16.67)$ & \\
\hline Married & $100(73.53)$ & $86(74.14)$ & $186(73.81)$ & \\
\hline Widowed & $11(8.09)$ & $3(2.59)$ & $14(5.56)$ & \\
\hline Widower & $5(3.68)$ & $1(0.86)$ & $6(2.38)$ & \\
\hline Divorce & $2(1.47)$ & $2(1.72)$ & $4(1.59)$ & \\
\hline \multicolumn{5}{|l|}{ Household Size } \\
\hline $1-5$ & $14(10.29)$ & $12(10.34)$ & $26(10.32)$ & \\
\hline $6-10$ & $47(34.56)$ & $47(40.52)$ & $94(37.30)$ & \\
\hline $11-15$ & $46(33.82)$ & $46(39.66)$ & $92(36.51)$ & \\
\hline$>15$ & $29(21.32)$ & $11(9.48)$ & $40(15.87)$ & $11 \pm 5.2$ \\
\hline \multicolumn{5}{|l|}{$\begin{array}{l}\text { Years of formal } \\
\text { education }\end{array}$} \\
\hline $\begin{array}{l}\text { No formal } \\
\text { education }\end{array}$ & $23(16.91)$ & $7(6.03)$ & $30(11.90)$ & \\
\hline $1-6$ & $29(21.32)$ & $47(40.52)$ & $76(30.16)$ & \\
\hline $7-12$ & $54(39.71)$ & $49(42.24)$ & $103(40.87)$ & \\
\hline$>12$ & $30(22.06)$ & $13(11.21)$ & $43(17.06)$ & $9 \pm 4.8$ \\
\hline \multicolumn{5}{|l|}{ Farming } \\
\hline \multicolumn{5}{|l|}{$\begin{array}{l}\text { Experience } \\
\text { (years) }\end{array}$} \\
\hline $1-10$ & $34(25.00)$ & $12(10.34)$ & $46(18.25)$ & \\
\hline $11-20$ & $61(44.85)$ & $55(47.41)$ & $116(46.03)$ & \\
\hline$>20$ & $41(30.15)$ & $49(42.24)$ & $90(35.71)$ & $18 \pm 8$ \\
\hline \multicolumn{5}{|l|}{ Farm Size $(\mathrm{Ha})$} \\
\hline$\leq 1.000$ & 19 (13.97) & $13(11.21)$ & $32(12.70)$ & \\
\hline $1.001-2.000$ & $48(35.29)$ & $69(59.48)$ & $117(46.43)$ & \\
\hline $2.001-3.000$ & $42(30.88)$ & $30(25.86)$ & $72(28.57)$ & \\
\hline
\end{tabular}

URL: http://journals.covenantuniversity.edu.ng/index.php/cjbss 


\begin{tabular}{lllll}
$>3.000$ & $27(19.85)$ & $4(3.45)$ & $31(12.30)$ & $2.32 \pm 0.86$ \\
$\begin{array}{l}\text { Agrochemicals } \\
\text { (Litres) }\end{array}$ & & & & \\
$\leq 200$ & $27(19.85)$ & $23(19.83)$ & $50(19.84)$ & \\
$201-400$ & $29(21.32)$ & $18(15.52)$ & $47(18.65)$ & \\
$401-600$ & $35(25.74)$ & $50(43.10)$ & $85(33.73)$ & \\
$601-800$ & $40(29.41)$ & $18(15.52)$ & $58(23.02)$ & $454.0 \pm 267.6$ \\
$>800$ & $5(3.68)$ & $7(6.03)$ & $12(4.76)$ & \\
Type of & Co- & & & \\
operative & & & & \\
Consumer & $40(29.41)$ & $36(31.03)$ & $76(30.16)$ & \\
Producer & $63(46.32)$ & $38(32.76)$ & $101(40.08)$ & \\
Multipurpose & $2(1.47)$ & $2(1.72)$ & $4(1.59)$ & \\
Others & $31(22.79)$ & $40(34.48)$ & $71(28.17)$ & \\
Land & & & & \\
System & & & & \\
Inheritance & $77(56.62)$ & $74(63.79)$ & $151(59.92)$ & \\
Lease & $16(11.76)$ & $8(6.90)$ & $24(9.52)$ & \\
Borrowed & $6(4.41)$ & $11(9.48)$ & $17(6.75)$ & \\
Purchased & $27(19.85)$ & $16(13.79)$ & $43(17.06)$ \\
Gift & $10(7.35)$ & $7(6.03)$ & $17(6.75)$ & \\
\hline
\end{tabular}

Source: Authors computation (2019). Figures in parenthesis are percentages.

\section{Profitability Level and Cost Structure of Irish Potato Farms}

Firstly, the results of the profitability analysis are presented on Table 3, per hectare of Irish potato farming in the study area. The result revealed a net farm income of $¥ 604,245.81$ per hectare which implies that on the average, an Irish potato farmer in the study area earns a profit of $\$ 604$, 245.81 on one hectare of land per year. This shows that the farmers were able to cover their total expenses with the level of net farm income obtained and had a sizeable proportion as profit, thus implying a profitable enterprise. This is in line with the findings of Okonkwo et al. (2009) and Jwanya et al. (2014) that, Irish potato farming enterprise is profitable.
Similarly, the Benefit-Cost ratio was greater than one (1.70) implying that the returns from Irish potato is economically satisfactory. Hence, for every 1 spent/cost incurred, the farmer receives a revenue of $\$ 1.70$, further confirming Irish potato farming as profitable. The return on investment (ROI) of 0.70 showed that the amount realized by farmers on every 11 spent on production was $¥ 0.70$ (70 kobo). Also, the NFI ratio which is the profitability ratio was 0.37 implying that for every 1 generated in sales of Irish potato; the farmer had $\cong 0.37$ (37kobo) leftover to cover total costs. These results implied that Irish potato production in Plateau state is a profitable and lucrative enterprise. 
Table 3: Profitability Analysis per Hectare of Irish Potato Farming

\begin{tabular}{|c|c|}
\hline Items & Value per ha (N) \\
\hline Total Revenue(A) & $1,499,463.51$ \\
\hline \multicolumn{2}{|l|}{ Variable Cost items: } \\
\hline Seed & 456520.17 \\
\hline Fertilizer & 141474.20 \\
\hline Agrochemicals & 16471.42 \\
\hline \multicolumn{2}{|l|}{ Labour Cost: } \\
\hline Land preparation & 50751.88 \\
\hline Planting & 32949.74 \\
\hline Fertilizer-application & 25772.54 \\
\hline Weeding & 40979.46 \\
\hline Harvesting & 44485.32 \\
\hline Total Labour Cost & 194938.94 \\
\hline Jute bags & 13319.43 \\
\hline Transportation & 34759.59 \\
\hline Total Variable Cost $(B)$ & $857,483.75$ \\
\hline Total Fixed Cost $(C)$ & $37,733.95$ \\
\hline Total Cost $(\mathrm{B}+\mathrm{C})$ & $895,217.70$ \\
\hline Gross Margin GM= (A-B) & $641,979.76$ \\
\hline NFI (GM-C) & $604,245.81$ \\
\hline Benefit-cost ratio (TR/TC) & 1.70 \\
\hline ROI(NFI/TC) & 0.70 \\
\hline NFI ratio (NFI/TR) & 0.37 \\
\hline
\end{tabular}

Note: $\$ 362.50 k$ (Naira, Nigerian currency) = USD\$1.00 as at October 2019.

Source: Authors computation (2019).

The profile of the Irish potato farmers' profitability level is presented on Table 4 using the average NFI. The result revealed that more than half the farmers $(53.97 \%)$ were at high profitability level. 
Table 4: Category of Irish potato Farmers based on Profitability Levels

\begin{tabular}{lcc}
\hline Profitability Level & Frequency & Percentage (\%) \\
\hline High Profitability & 136 & 53.97 \\
Low Profitability & 116 & 46.03 \\
Total & 252 & 100.00 \\
Mean=604245.8 & & \\
S.D = 373611.1 & & \\
\hline
\end{tabular}

Source: Authors computation (2019).

The cost structure helps to provide insight into what input constitutes the larger proportion of the total cost production (Bekele et al., 2019). This is to enable Irish potato farmers to adopt a better plan for the farming enterprise. The result in Table 5 showed that the average total variable cost ( $\$ 857$, 483.75) accounted for about $95.78 \%$ of the total cost of production ( $\$ 895$, 217.70). Fixed costs ( $\$ 37,733.95)$, on the other hand, accounted for only $4.22 \%$ of the total cost of production. This finding confirmed the observation of Olukosi and Erahbor (2005) that the fixed cost of production is usually negligible in subsistence agricultural system. The average cost of seed per hectare ( $\$ 456,520.17$ ) accounted for $51.00 \%$ of the total cost of production and the highest variable cost component, followed by the cost of labour ( $194,938.94)$ which accounted for $21.78 \%$ and fertilizer ( $\$ 141,474.20)$ accounting for $15.80 \%$. This agrees with the findings of Jwanya et al. (2014) and Kakuongo et al. (2008), that costs of seeds, labour and fertilizer make up the highest proportion of the average total cost of production per hectare of Irish potato and constitute the major challenges in Irish potato industry in most developing African countries. This finding suggests the need for resource use efficiency in Irish potato farming in order to maximize profit.

Table 5: Cost Structure per Hectare of Irish Potato Farming

\begin{tabular}{lll}
\hline Items & Cost ( ) & $\begin{array}{l}\text { Percentage (\%) } \\
\text { of Total cost }\end{array}$ \\
\hline Variable Cost items: & $456,520.17$ & 51.00 \\
Cost of seed & $141,474.20$ & 15.80 \\
Cost of Fertilizer & $16,471.42$ & 1.84 \\
Cost of Agrochemicals & $194,938.94$ & 21.78 \\
Total Labour Cost & $13,319.43$ & 1.49 \\
Cost of Jute bags & $34,759.59$ & 3.88 \\
Transportation cost & $857,483.78$ & 95.78 \\
Total Variable Cost (TVC) & & \\
Fixed Cost: & &
\end{tabular}

URL: http://journals.covenantuniversity.edu.ng/index.php/cjbss 


\section{Rent on land \\ Total Fixed Cost (TFC) \\ Total Cost $(T V C+T F C)$ \\ Source: Authors Computation (2019). \\ Determinants of Profitability Level of Irish Potato Farming}

$37,733.95$

$37,733.95$

$895,217.70$
4.22

4.22

100.00
The probit regression estimates for the determinants of profitability level of Irish potato farms in the study area are presented in Table 6 . The Wald $\chi 2$ test for the overall performance of the model indicates that we cannot accept the null hypothesis, that all coefficients are equal to zero. Thus, the coefficients of the probit regression model, just like those of other discrete choice models cannot be interpreted directly. They are transformed into marginal effects, interpreted as the change in predicted probability associated with the changes in the exogenous variables. The results further showed that farm size, labour, sex and agrochemicals significantly determine the probability that Irish potato farmers will have high level of profitability in the study area, at $1 \%$ level respectively.

Farm size had a negative influence (0.1961 ) on the probability of having high profitability level. This implies that a hectare increase in the farm size of the farmers reduces the probability of the farmer being highly profitable by $19.61 \%$. In other words, the larger the farm size, the lower the probability of being highly profitable. This may be attributed to farmers cultivating more farmland than they can manage; thus, leading to inefficiency in production and consequently affecting their profitability. This finding is contrary to a priori expectation but similar to the results of Sebatta et al. (2015) who found that cultivating larger farmland leads to lower profitability levels. Similarly, labour input was negative (0.0086) and in influencing the profitability level of Irish potato farming. Hence, an additional one unit of labour used reduces the probability of the farmer having a high profitability level by $0.86 \%$. This could arise especially when the farmer relies on some form of hired labour (communal labour as observed in the study area) given the number of persons involved and the cost attached to this labour. This increases the cost of production and in turn affects the profitability of the farmer. The result is in line with a priori expectation; and similar to that of Aheisibwe et al. (2017) who found that labour input had a negative significant influence on the profitability of smallholder farmers.

On the other hand, being a male farmer had a positive (0.3782) relationship with the probability of having a high profitability level. This implies that male farmers in the study area had a $37.82 \%$ higher chance to increase their profitability level than their female counterparts. This could be due to the amount of energy and drudgery involved in the traditional system of farming practised in the area. Moreover, women have less access to land, labour supply and other production resources 
due to cultural prejudice. Men are also more likely to participate in most farm activities thereby reducing their cost of production, particularly labour. Juma (2013) found similar results on the relationship of gender to increase the probability of being profitable. Similarly, the use of agrochemicals had a positive relationship indicating that for a unit increase in the amounts of agrochemicals applied, there would be an increase in the probability of the farmer having a high profitability level by a magnitude of $0.06 \%$. This is expected and agrees with Otitolaiye et al. (2014) who found that farmers who apply the recommended amounts of chemicals get higher yields which reflect in their profitability level.

Table 5: Probit Regression Estimates for the Determinants of Profitability level

\begin{tabular}{lccccc}
\hline Profitability & Coefficient & $\begin{array}{c}\text { Marginal } \\
\text { effects }\end{array}$ & Std. Err. & Z-value & $\mathbf{P}>|\mathbf{z}|$ \\
\hline Constant & 0.1199 & & 0.4291 & 0.28 & 0.780 \\
Years of education & 0.0030 & $0.0009 \mathrm{~ns}$ & 0.0211 & 0.14 & 0.888 \\
Access to credit & 0.2507 & $0.0769 \mathrm{~ns}$ & 0.2180 & 1.15 & 0.250 \\
Marital status & 0.0964 & $0.0298 \mathrm{~ns}$ & 0.2879 & 0.33 & 0.738 \\
Farming & 0.0102 & $0.0032 \mathrm{~ns}$ & 0.0137 & 0.74 & 0.459 \\
experience & -0.6389 & $-0.1961^{* * * *}$ & 0.2022 & -3.16 & 0.002 \\
Farm size & -0.0354 & $-0.0109 \mathrm{~ns}$ & 0.0221 & -1.60 & 0.110 \\
Household size & 0.00003 & $7.96 \mathrm{E}-06 \mathrm{~ns}$ & 0.0001 & 0.48 & 0.632 \\
Seed & -0.0281 & $-0.0086^{* * *}$ & 0.0103 & -2.74 & 0.006 \\
Labour & 1.231 & $0.3782^{* * *}$ & 0.2471 & 4.98 & 0.000 \\
Sex & -0.1221 & $-0.0377 \mathrm{~ns}$ & 0.2420 & -0.50 & 0.614 \\
Type of & & & & & \\
cooperative & -0.0438 & $-0.0136 \mathrm{~ns}$ & 0.3366 & -0.13 & 0.897 \\
Land tenure & & & & & \\
System & 0.0021 & $0.0006^{* * *}$ & 0.0006 & 3.39 & 0.001 \\
Agrochmemicals & 0.001 & & & \\
Wald $\chi^{2}(20)=$ & & & & & \\
75.31 & & & & & \\
Prob $>$ & & & & & \\
$\chi^{2}=0.0000 * * *$ \\
Pseudo $\mathrm{R}^{2}=0.2119$
\end{tabular}

Source: Authors computation (2019). *** Significant at 1\% probability level and ns not significant.

\subsection{Conclusion}

Irish potato is widely cultivated in commercial quantities in Plateau state; contributing to the food chain of households, nutrition, livelihood diversification and income. It was found in this study that Irish potato farming in Plateau State was profitable. Thus, as government ramp up efforts to improve

URL: http://journals.covenantuniversity.edu.ng/index.php/cjbss 
Irish potato production in Plateau State through seeds multiplication, training of farmers, Irish potato research, breeding and selection of new varieties that are capable of responding to improved cultural practices, efforts should also be stepped up at encouraging new entrants into the enterprise. The factors that determine the profitability level of Irish potato farming are farm size, labour, sex and agrochemicals. Therefore, government and non-governmental agencies should pursue programmes that ensure reduced costs on inputs, particularly agrochemicals, for Irish potato farmers. This will encourage increased use of inputs among the farmers until the recommended levels are met. In addition, proper

\section{References}

Adekanye, J.O. and Oyekale, A.S. Profitability and Technical Efficiency of Sweet Potato Production in Osun State, Nigeria. International Journal of Current Research \& Academic Review, 3 (1): 232-241.

Aheisibwe, A. R., Etiang, J., Ashaba, D., Kwikiriza, G., Muhereze, R. \& Barekye, A. (2017). Profitability of apple enterprise among small-holder farmers in South Western Highland AgroEcological Zone ( SWHAEZ) of Uganda. Journal of Development and Agricultural Economics, 9(July), 190-199. https://doi.org/10.5897/JDAE201 6.0805

Ashley-Dejo, S. S., Omoniyi I. T., Olaoye, O. J., Fakoya, E. O. \& management methods of farm size and labour should be encouraged among the farmers. This could be achieved through the use of extension services and cooperatives. Being a male farmer improves the profitability level of a potato farmer. This may indicate that female farmers are being marginalized in the enterprise. Therefore, government should put in place policies that will encourage women farmers' profitability levels. Further, continued advocacy and campaign for women's rights and against noisome cultures that limit women should be undertaken by both government and non-governmental agencies, to increase women farmers' profitability levels.

Adelaja, O. A. (2016). Adoption of improved fish hatchery production technologies by fish hatchery managers in Oyo State Nigeria. Nigerian J. Animal Production, Vol. 2, pp. 399-411.

Bathon, A. H., Maurice, D. C., Jongur, A. A. U. \& Shehu, J. F. (2016). Profitability Of Groundnut-Based Cropping Systems Among Farmers In Hong Local Government Area Of Adamawa State. Nigeria. Global Journal Of Agricultural Sciences, Vol. 15, pp. 1-9.

Bekele, A., Chanyalew, S., Damte, T., \& Husien, N. (2019). Cost-benefit Analysis of New Tef ( Eragrostis tef ) Varieties under Lead Farmers , Production Management in the Central Ethiopia. Ethiop. J. Agric. Sci., 29(1), 109-123.

URL: http://journals.covenantuniversity.edu.ng/index.php/cjbss 
Dimlong S.Y. (2012). Best Practices on potato (Solanum tubersum L) Production and storage", pp18. German Agency for International Co-operation GIZ. Abuja Nigeria.

FAOSTAT (2015). Food and Agricultural Organization of the United Nations. FAO Statistical Database 2015. Retrieved 04/07/2015 from World Wide Web

http://www.potatopro.com/world/ potato-statistics

FAOSTAT (2016). Food and Agricultural Organization of the United Nations. FAO Statistical Database 2015. Retrieved 7/1/2016 from World Wide Web http://faostat3.fao.org/download/ $\mathrm{FB} / \mathrm{CC} / \mathrm{E}$

FAOSTAT (2019). Food and Agricultural Organization of the United Nations. FAO Statistical Database. Retrieval date January 5, 2019, from World Wide Web http://www.potatopro.com/world/ potato-statistics

http://www.fao.org/faostat/en/dat a

Gebru, H., Mohammed, A., Dechassa, N. \& Belew, D. (2017). Assessment of production practices of smallholder potato (Solanum tuberosum L.) farmers in Wolaita Zone, southern Ethiopia. Agriculture \& Food Security, 6 (31): $\quad$ DOI 10.1186/s40066-017-0106-8

Gujarati, D.N. (2004). Basic Econometrics. Fourth edition, McGraw Hill Companies.

Haruna, V. (2010). Economics of cassava production in Jama'a
Local Government Area of Kaduna State: A Comparative Analysis of Local and Improved varieties. Unpublished M.Sc. Thesis, Department of Agricultural Economics and Rural Sociology, Ahmadu Bello University, Zaria

Jatbong, J.N., Sani, R.M., Salawu, J.A. \& Suleiman, H.R. (2018). Economic Efficiency of Male and Female Potato Farmers in Plateau State, Nigeria: A Translog Profit Function Approach. Direct Research Journal of Agriculture \& Food Science, 6 (12), 378-384.

Juma, O. M. (2013). Essays on farm technology adoption, technical efficiency and productivity in smallholder food crop agriculture in kenya. Unpublished Ph.D Thesis Kenyatta University.

Jwanya, B.A., Dawang, N.C., Zarmai, D.U. \& Mashat, I.M. (2014). Economic Analysis Irrigated Irish Potato production in Plateau State, Nigeria. Savannah Journal of Agriculture. 3(1):47-52.

Kakuongo,W.P, Gildemacher, P., Demo, P, Wagiore, W, Kinyae, P, Andrade P, Farbes, G, Fuglie, K. \& Thiele. (2008). Farmer practices and Adoption of improved potato varieties in Kenya and Uganda. AKARI Publication pp. 27 -32.

Kudi, T.M., Akpoko, J.G., \& Yada, P. (2008). Resource productivity and profitability

Analysis of Irish potato production in Plateau State, Nigeria. Savannah Journal of Agriculture. 3(1): 4752.

URL: http://journals.covenantuniversity.edu.ng/index.php/cjbss 
Lenka, D.M., Asumugha, G.N., Dung, E.A., \& Nwauzor, E.C. (2006). Socio-economic

Analysis of Farming Risk in Potato Production in Plateau State", In: Adepoju, S.O and Okuneye, P.D (ed), "Technology and agricultural development in Nigeria”, Farm Management Association of Nigeria (FAMAN): Proceedings of 20th Annual National Conference. Sept. 18- 21st: pp. 337-340, held at Federal College of Forestry Jos, Nigeria.

Masuku, M. B., Raufu, M. O. \& Malinga, N. G. (2015). The Impact of Credit on Technical Efficiency Among Vegetable Farmers in Swaziland. Sustainable Agriculture Research:Published by Canadian Center of Science and Education, 4(1), 114-126. https://doi.org/10.5539/sar.v4n1p 114

Muhammad, A., Gindi, A.A., Gona, A. \& Kaka, Y. (2016). Partial Economic Analysis of Irish Potato Production under Kebbi State Agroecological Conditions. International Journal of Life Sciences Scientific Research, 2 (2): 183-190.

Njuguna, I.M., Munyua, C.N. and Makal, S.K. 2014. Influence of Demographic

Characteristics on Adoption of Improved potato Varieties by Small-holder farmers in Mumberes Division. Baringo Country, Kenya. Journal of
Agricultural Extension and Rural Development. 7(4):115-121.

Nweze, N. J. \& Panwal E. F. (2006).

Resource- use and productivity among rainfed and irrigated Irish Potato Producers in Plateau State, Nigeria. A paper presented at 20th Annual National Conference of Farm Management Association of Nigeria, held at Forestry Research Institute of Nigeria, Federal College of Forestry, Jos Plateau, 18th-21stSeptember, 2006

Nyagaka, D.O., Obare, G.A. and Nguyo, W. 2009. Economic Efficiency of Small-holder Irish Potato Producers in Kenya: A case of Nyandarua North District. Being a paper presented at the International Conference of the Economists, Beijing, China, August 16th-22nd, pp. 2-19.

Obare, G.A., Nyagaka, D.O., Nguyo, W. and Mwakubo, S.M. 2010. Are Keyan smallholders Allocatively efficient? Evidence from Irish potato producers in Nyandarua North District. Journal of Development and Agricultural Economics.2 (3):78-85

Ogunleye, A. S., \& Adeyemo R. (2017). Assessment of profitability and efficiency of cassava production among government and non-government assisted farmers association in Osun State, Nigeria. African Journal of Rural Development, pp. 225-233.

Ojo, F.T. (2013). Potato Production in the Tropics. Unpublished M.Sc 
project. University of Ibadan, 40$60 \mathrm{pp}$

Okonkwo, J.C; Amadi, C.O. \& Nwosu, K.I. (2009). Potato Production, Storage, Processing and utilization in Nigeria. (2nd ed.). Umudike: NRCRI.

Okoye, B.C., Onyenweaku, C. E. and Agwu, A.E. 2008.Technical efficiency of small holder cocoyam farmers in Anambra state Nigeria. Implications for agricultural extension policy. Journal of Agricultural Extension, 12(1)

Olayide, S.O. \& Heady E.O. (1982). Introduction to Agricultural Production Economics. Ibadan, University Press, Ibadan, Nigeria. Olukosi, J.O \& Erhabor, P.O. (2005). Introduction to Farm Management Economics:

Principles and Applications. Zaria: Agitab publishers' Ltd.

Otitolaiye, J. O., Ohajianya, D. O., Saliu, O. J., Ibitoye, S. J., Ibekwe, U. C. \& Anaeto, F. C. (2014). Technical Efficiency of Sweet Potato Farmers in Okene Local Government Area of Kogi State, Nigeria. Asian Journal of Agricultural Extension, Economics \& Sociology, pp. 108117.

Panwal E.F. (2018). Resource Use and Productivity Among Rain-Fed and Irrigated Irish Potato Producers in Plateau State, Nigeria. Journal of Agriculture and Sustainability, 11(1), 1-10.

Sanusi, M. M. \& Babatunde, D. A. (2017). Analysis of Potato Consumption among Households in Odeda Local Government Area , Ogun State, Nigeria. Agricultura Tropica et Subtropica, 2(50), 89-99. https://doi.org/10.1515/ats

Sebatta, C., Mugisha, J., Katungi, E., Kasharu, A. K. \& Kyomugisha, H. (2015). Adding Value at the Farm: The Case of Smallholder Potato Farmers in the Highlands of Uganda. Asian Journal of Agricultural Extension, Economics \& Sociology, 4(December 2011), 210-223. https://doi.org/10.9734/AJAEES/ 2015/13844

Sher, A., Zeeshan, M., Gilani, S., Mustafa, G., \& Mushtaq, K. (2016). Investigation of the Factors Affecting the Potato Production with Special Reference to Farmers Entrepreneurial Level in Punjab, Pakistan. Journal of Agriculture \& Basic Sciences, 1 (2), 30-37.

Sujan, H. K., Islam, F., Azad, J., \& Rayhan, S. J. (2017). Financial profitability and resource use efficiency of boro rice cultivation in some selected area of. African Journal of Agricultural Research, 12(29), 2404-2411. https://doi.org/10.5897/AJAR201 7.12443

Tadesse, B., Bakala, F. \& Mariam, L. W. (2018). Assessment of postharvest loss along potato value chain: the case of Sheka Zone , southwest Ethiopia. Agriculture \& Food Security, 114. https://doi.org/10.1186/s40066018-0158-4 
Taiy, R. J., Onyango, C., Nkurumwa, A. \& Ngetich, K. (2017). Socioeconomic Characteristics of Smallholder Potato Farmers in Mauche Ward of Nakuru County Kenya, 5(5), 257-266. https://doi.org/10.13189/ujar.201 7.050502

Tolno, E., Kobayashi, H., Ichizen, M. \& Balde, B.S. (2016). Potato production and Supply by Smallholder Farmers in Guinea: An Economic Analysis. Asian Journal of Agricultural Extension, Economics \& Sociology, 8 (3): 116.

Udensi, U. E., Henri-ukoha, A., Iyangbe, C., \& Harcourt, P. (2017). Profitability of YamMaize-Soybean Enterprise among Resource Poor Farmers Using Herbicide for Weed Control in the Northern Guinea Savanna. Journal of Experimental Agriculture International, 19(2), $1-10$.

https://doi.org/10.9734/JEAI/201 7/37631

Ugonna, C.U., Jolaoso, M.O. \& Onwualu, A.P. (2013). A
Technical Appraisal of Potatto Value Chain in Nigeria. International Research Journal of Agricultural Science \& Soil Science, 3 (8).

Wuyep, S. Z., Zemba, A. A. \& Jahknwa, C. J. (2013). Effects of precipitation effectiveness on the yield of Irish potato ( solanum tuberosum ) in Jos-plateau , Nigeria. International Journal of Research in Applied, Natural and Social Sciences (IMPACT:, 1(5), 27-32.

Zemba, B. A. A., Wuyep, S. Z., Adebayo, A. A. \& Jahknwa, C. J. (2013). Growth and Yield Response of Irish Potato ( Solanum Tuberosum ) to Climate in Jos-South, Plateau State , Nigeria. Global Journal of human social science Geography, GeoSciences, Environmental Disaster Management, 13(5), 13-18.

Zhang, L., Su, W., Eriksson, T. \& Liu, C. (2016). How Off-farm Employment Affects Technical Efficiency of China', s Farms : The Case of Jiangsu. China \& World Economy, 24(3), 37-51. 